\section{Birth weight of indigenous children in Brazil: results of the First National Survey of Indigenous People's Health and Nutrition}

\author{
Peso ao nascer de crianças indígenas no Brasil: \\ resultados do Primeiro Inquérito Nacional de \\ Saúde e Nutrição dos Povos Indígenas
}

\section{Peso al nacer de niños indígenas en Brasil: resultados de la Primera Encuesta Nacional sobre la Salud y Nutrición de los Pueblos Indígenas}

COMUNICAÇÃO BREVE

BRIEF COMMUNICATION

\author{
Aline Alves Ferreira 1 \\ Mirian Carvalho de Souza 2 \\ Andrey Moreira Cardoso 3 \\ Bernardo Lessa Horta 4 \\ Ricardo Ventura Santos 3,5 \\ James R. Welch 3 \\ Carlos E. A. Coimbra Jr. 3
}

\begin{abstract}
Birth weight is an important predictor of perinatal, infant, and preschool-age children morbimortality. However, information about indigenous children's birth weight is still scarce. This study aimed to analyze the birth weight of indigenous children based on data from the First National Survey of Indigenous People's Health and Nutrition, Brazil (2008-2009). This is the first study to address indigenous children's birth weight based on a nationwide representative sample. Mean birth weights and the respective standard deviations were calculated according to geopolitical region, sex, type of birth, and birthplace. The chi-square test was used to analyze differences in proportions, and Kruskal-Wallis and Mann-Whitney U tests in means, considering sample design and data normality. We found no records on birth weight in the researched documents for $26.7 \%$ of the 6,128 sampled children. The mean birth weight for the 3,994 children included in the analyses was 3,201g (standard deviation - SD $\pm 18.6 \mathrm{~g}$ ), regardless of sex, type of birth, and birthplace. The prevalence of low birth weight was $7.6 \%(n=302)$ and was significantly higher among girls. Boys presented significantly higher mean birth weight than girls, regardless of the geopolitical region. Low birth weight was slightly less frequent among indigenous children when compared to Brazilian children in general. Our study indicates the need to improve prenatal care and the quality of consultation records for indigenous women as a strategy to promote safe pregnancy and childbirth.
\end{abstract}

Health of Indigenous Peoples; South American Indians; Birth Weight; Child Health; Health Inequality Indicators

\author{
Correspondence \\ A. A. Ferreira \\ Instituto de Nutrição Josué de Castro, Universidade Federal do \\ Rio de Janeiro. \\ Av. Carlos Chagas Filho 373, bloco J, 2o andar, sala 18, Rio de \\ Janeiro, RJ 21941-902, Brasil. \\ alineaf@nutricao.ufrj.br
${ }^{1}$ Instituto de Nutrição Josué de Castro, Universidade Federal do Rio de Janeiro, Rio de Janeiro, Brasil.
2 Coordenação de Prevenção e Vigilância, Instituto Nacional de Câncer, Rio de Janeiro, Brasil.
3 Escola Nacional de Saúde Pública Sergio Arouca, Fundação Oswaldo Cruz, Rio de Janeiro, Brasil.
4 Programa de Pós-graduação em Epidemiologia, Universidade Federal de Pelotas, Pelotas, Brasil.
5 Museu Nacional, Universidade Federal do Rio de Janeiro, Rio de Janeiro, Brasil.




\section{Introduction}

Birth weight is an important predictor of perinatal, infant, and preschool-age children morbimortality, associated with diverse health outcomes in childhood and adulthood 1,2. Recent Brazilian studies based on data from the Brazilian Information System on Live Births (SINASC) and local birth cohorts stressed the role of socioeconomic factors, access to prenatal care, increased rates of cesarian sections, and early-term births in determining low birth weitht 3,4.

Recent studies reported pronounced health disparities separating Brazilian non-indigenous from indigenous children, who experience elevated rates of mortality, chronic undernutrition, preventable infectious diseases, and inadequate prenatal care 5,6,7. Information about indigenous children's birth weight is scarce and often restricted to a limited number of people within specific ethnic groups 8,9,10.

This study aimed to analyze the birth weight of indigenous children using data from the First National Survey of Indigenous People's Health and Nutrition in Brazil (henceforth, "National Survey"), conducted in 2008-2009 5. This is the first study to address indigenous children's birth weight based on a nationwide representative sample.

\section{Methodology}

The National Survey assessed the nutritional status and other health indicators of 6,128 indigenous children aged less than 5 years (93.1\% of the planned sample), employing a representative probabilistic sample of the indigenous population residing in 113 Brazilian villages from four geopolitical regions: North, Northeast, Central, and South/Southeast 5. Data on birth weight, birthplace, and type of birth were collected from children's health records or vaccination cards. Further details about the study methodological design can be found in Coimbra Jr. et al. 5.

For analyses, we considered the cut-off points for low birth weight $<2,500 \mathrm{~g}$, normal birth weight from $2,500 \mathrm{~g}$ to $4,499 \mathrm{~g}$, and macrosomia $\geq 4,500 \mathrm{~g}$.

Birthplace was classified as "village" or "health unit" (hospitals, maternity wards, and indigenous health units).

Statistical analysis was performed considering the complex sampling design. Mean birth weights and their respective standard deviations (SD) were calculated according to region, sex, type of birth, and birthplace. The chi-square test was used to analyze differences in proportions, and Kruskal-Wallis and Mann-Whitney $\mathrm{U}$ tests in means, considering sample design and data normality. All tests were conducted considering a 95\% significance level. Analyses were performed using IBM SPSS Statistics for Windows, version 21.0 (https://www.ibm.com/).

The study was approved by the Brazilian National Commission for Research Ethics (n. 256/2008) and the Brazilian National Indian Foundation.

\section{Results}

We found no records on birth weight for $26.7 \%$ of the 6,128 sampled children in the researched documents. The North region had the highest number of children without birth weight data (51\%), while the other regions presented less than 30\% of missing data, ranging from $18.3 \%$ (Northeast) to 26.7\% (South/Southeast) (Table 1). Although missing data on birth weight had no significant difference regarding sex, we found important differences according to birthplace and type of birth. In the North, 78.5\% $(n=1,035)$ of births without data on birth weight occurred in villages, whereas this value was only $21.2 \%$ in the South/Southeast. Cesarean deliveries performed in the South/Southeast and Northeast presented high percentages of missing birth weight data ( $15.2 \%$ and $10.1 \%$, respectively).

The mean birth weight for the 3,994 children analyzed (65.2\% of the total sample) was $3,201 \mathrm{~g}$ $(\mathrm{SD} \pm 18.6 \mathrm{~g})$, regardless of sex, type of birth, and birthplace. The prevalence of low birth weight was $7.6 \%(\mathrm{n}=302)$. Low birth weight ranged from $7.3 \%$ in the Northeast to $7.9 \%$ in the Central. The Northeast showed the highest mean birth weight $(3,264 \mathrm{~g})$, while the Central had the lowest $(3,137 \mathrm{~g})$ (Table 1). 
Table 1

Distribution of low birth weight $(<2,500 \mathrm{~g})$ and mean birth weight by geopolitical region, sex, type of birth, and birthplace. First National Survey of Indigenous People's Health and Nutrition, Brazil, 2008-2009.

\begin{tabular}{|c|c|c|c|c|c|c|c|c|c|c|}
\hline \multirow[t]{3}{*}{ Variables } & \multicolumn{10}{|c|}{ Birth weight } \\
\hline & \multicolumn{2}{|c|}{ Available data } & \multicolumn{2}{|c|}{ Missing } & \multirow[t]{2}{*}{ p-value * } & \multicolumn{3}{|c|}{ Low birth weight ** } & \multirow[t]{2}{*}{ p-value *** } & \multirow{2}{*}{$\begin{array}{c}\text { Mean birth } \\
\text { weight (g) (SD) }\end{array}$} \\
\hline & $\mathbf{n}$ & $\%$ & $\mathbf{n}$ & $\%$ & & $\mathbf{n}$ & $\%$ & $95 \% \mathrm{Cl}$ & & \\
\hline Brazil & 3,994 & 73.3 & 2,134 & 26.7 & & 302 & 7.6 & $6.6 ; 8.8$ & & 3,201 (18.6) \\
\hline \multicolumn{11}{|l|}{ Geopolitical region } \\
\hline North & 1,265 & 49.0 & 1,319 & 51.0 & $<0.001$ & 95 & 7.5 & $5.1 ; 11.0$ & 0.970 & $3,161(30.2)$ \\
\hline Central & 972 & 75.1 & 332 & 24.9 & & 77 & 7.9 & $6.7 ; 9.3$ & & $3,137(30.9)$ \\
\hline Northeast & 1,108 & 81.7 & 247 & 18.3 & & 81 & 7.3 & $5.9 ; 9.1$ & & $3,264(25.2)$ \\
\hline South/Southeast & 649 & 73.3 & 236 & 26.7 & & 49 & 7.7 & $5.4 ; 10.8$ & & 3,216 (35.7) \\
\hline \multicolumn{11}{|l|}{ Sex } \\
\hline Male & 2,075 & 71.3 & 1,073 & 28.7 & 0.118 & 139 & 6.7 & $5.5 ; 8.1$ & 0.049 & $3,250(22.6)$ \\
\hline Female & 1,918 & 69.3 & 1,061 & 30.7 & & 163 & 8.6 & $7.1 ; 10.4$ & & $3,148(18.0)$ \\
\hline \multicolumn{11}{|l|}{ Type of birth } \\
\hline Vaginal & 3,430 & 69.0 & 1,963 & 31.0 & $<0.001$ & 8 & 7.2 & $6.1 ; 8.4$ & 0.032 & 3,198 (19.8) \\
\hline Cesarean & 511 & 81.2 & 118 & 18.8 & & 49 & 10.3 & $7.6 ; 13.7$ & & $3,222(30.1)$ \\
\hline \multicolumn{11}{|l|}{ Birthplace } \\
\hline Health unit ** & 2,877 & 79.0 & 801 & 21.0 & $<0.001$ & 194 & 7.1 & $6.1 ; 8.3$ & 0.153 & 3,223 (19.7) \\
\hline Village & 1,106 & 50.4 & 1,319 & 49.6 & & 107 & 9.5 & $6.6 ; 13.5$ & & $3,120(32.1)$ \\
\hline
\end{tabular}

95\%Cl: 95\% confidence interval; SD: standard deviation.

* Chi-square p-value comparing informed $\times$ uninformed birth weight;

$\star *<2,500$;

*** Chi-square p-value comparing low birth weight and adequate birth weight;

Only $0.6 \%$ of the sample $(\mathrm{n}=18)$ was born with very low birth weight $(<1,500 \mathrm{~g})$, with an average weight of $1,223 \mathrm{~g}(\mathrm{SD} \pm 103.8 \mathrm{~g})$. Of these, 96.3\% occurred in health units and mainly in the South/ Southeast $(51.7 \%$ - data not shown in table). Moreover, $1 \%(n=39)$ of the sample presented macrosomia.

The regional prevalence of low birth weight among children born in villages, where the highest percentage of data loss occurred, showed slightly higher values than that observed nationally (North: 10.3\%; Central: 9.8\%; Northeast: 7.5\%; and South/Southeast: 9.8\% - data not shown in table).

The prevalence of low birth weight was significantly higher among girls ( $\mathrm{p}$-value $<0.05$ ), and boys presented significantly higher mean birth weight than girls, regardless of the region ( $\mathrm{p}$-value $<0.05)$ (Table 1).

Cesarean sections had a higher percentage of low birth weight (10.3\%) than vaginal deliveries (7.2\%). The average birth weight of children born by vaginal delivery was $3,198 \mathrm{~g}(\mathrm{SD} \pm 19.8)$ - slightly, but significantly lower than those born by cesarean section, whose average birth weight was $3,222 \mathrm{~g}$ (SD \pm 30.1g; p-value < 0.001).

The percentage of low birth weight was higher for deliveries performed in villages (9.5\%) than for those performed in health units (7.1\%). The average birth weight for children born in health units was 3,223g ( $\mathrm{SD} \pm 19.7 \mathrm{~g})$ - slightly, but significantly higher than those born in villages, whose value was 3,120g (SD $\pm 32.1 \mathrm{~g} ; \mathrm{p}<0.001)$. Only 11 of the 2,877 births performed in health units occurred in indigenous health units, all of which in the North region (data not shown in table). 


\section{Discussion}

For over half a century, low birth weight has been considered a factor strongly associated with infant mortality and a barrier for a healthy childhood. Several studies worldwide reported an association between low birth weight and lifelong disabilities, such as hearing loss, chronic lung diseases, and cognitive impairment 1,2 .

Our study is the first nationwide investigation to address birth weight in Brazilian indigenous children. However, we were unable to access information on gestational age due to the inadequate coverage and quality of prenatal care for indigenous women in the country 7 , making it impossible for us to assess intrauterine growth. Another limitation is the large number of sampled children without data on birth weight. Surprisingly, we also found this deficiency in maternal and child health services affecting the indigenous population to occur in regions with better socioeconomic indicators. The South/Southeast and Northeast, for example - regions with better hospital infrastructure and more qualified health professionals than the North and Central - had high percentages of data loss regarding the birth weight of indigenous children even for deliveries performed in health units. Therefore, our data on birth weight should be interpreted critically. Given the greater data loss for children born in villages, the prevalence of low birth weight may be underestimated.

Our results show that the average birth weight of Brazilian indigenous children of both sexes, regardless of the type of delivery $(3,201 \mathrm{~g})$, is very close to that reported by Wehby et al. $11(3,127.5 \mathrm{~g})$.

Based on data from the National Survey, we found slightly lower frequency of low birth weight (7.6\%) among indigenous children than that observed in Brazilian children in general (8.1\%) 3. Regarding the type of birth, data from the National Survey indicate a higher prevalence of low birth weight among indigenous children born by cesarean sections (10.3\%), which tends to be observed in the general population due to the association between surgical delivery and preterm labor ${ }^{4}$. We also verified a higher frequency of low birth weight among children born in villages (9.5\%), which may reflect less coverage and lower quality of primary healthcare within these areas.

Our results highlight the need to improve prenatal care for indigenous women as a strategy to promote safe pregnancy and childbirth. These measures will provide more qualified information about the pregnancy evolution and, consequently, records on the birth weight of indigenous children, regardless of the place or type of birth. 


\section{Contributors}

A. A. Ferreira and M. C. Souza contributed in the data collection, statistical analyses, manuscript draft, final version reading and approval. A. M. Cardoso, B. L. Horta, R. V. Santos, J. R. Welch and C. E. A. Coimbra Jr. contributed in the research concept and design, data collection, final version reading and approval.

\section{Additional informations}

ORCID: Aline Alves Ferreira (0000-0001-50813462); Mirian Carvalho de Souza (0000-0001-75161974); Andrey Moreira Cardoso (0000-0002-75917791); Bernardo Lessa Horta (0000-0001-9843412X); Ricardo Ventura Santos (0000-0001-5071443X); James R. Welch (0000-0002-9094-5491); Carlos E. A. Coimbra Jr. (0000-0003-4085-1080).

\section{Acknowledgments}

The authors are grateful for the assistance offered by indigenous leaders and community members of all surveyed villages, as well as the local staff at the Brazilian National Indian Foundation (FUNAI) and Brazilian National Health Foundation (FUNASA). The administrative support provided by the staff of the Brazilian Public Health Association (Abrasco) greatly facilitated travel and financial logistics.

\section{References}

1. Wilcox AJ. On the importance - and the unimportance - of birthweight. Int J Epidemiol 2001; 30:1233-41.

2. Blencowe H, Cousens S, Chou D, Oestergaard M, Say L, Moller A-B, et al. Born too soon: the global epidemiology of 15 million preterm births. Reprod Health 2013; 10 Suppl 1:S2.

3. Andrade CLT, Szwarcwald CL, Castilho EA. Baixo peso ao nascer no Brasil de acordo com as informações sobre nascidos vivos do Ministério da Saúde, 2005. Cad Saúde Pública 2008; 24:2564-72.

4. Silveira MF, Victora CG, Horta BL, Silva BGC, Matijasevich A, Barros FC. Low birthweight and preterm birth: trends and inequalities in four population-based birth cohorts in Pelotas, Brazil, 1982-2015. Int J Epidemiol 2019; 48 Suppl 1:i46-53.

5. Coimbra Jr. CEA, Santos RV, Welch JR, Cardoso AM, Souza MC, Garnelo L, et al. The First National Survey of Indigenous People's Health and Nutrition in Brazil: rationale, methodology, and overview of results. BMC Public Health 2013; 13:52.

6. Santos RV, Borges GM, Campos MB, Queiroz BL, Coimbra Jr. CEA, Welch JR. Indigenous children and adolescent mortality inequity in Brazil: What can we learn from the 2010 National Demographic Census? SSM Popul Health 2020; 10:100537.

7. Garnelo L, Horta BL, Escobar AL, Santos RV, Cardoso AM, Welch JR, et al. Avaliação da atenção pré-natal ofertada às mulheres indígenas no Brasil: achados do Primeiro Inquérito Nacional de Saúde e Nutrição dos Povos Indígenas. Cad Saúde Pública 2019; 35 Suppl 3:e00181318.

8. Barreto CTG. Prevalência de baixo peso ao nascer e fatores associados em crianças indígenas Guarani no Sul e Sudeste: uma análise na linha de base da primeira coorte de nascimentos indígenas no Brasil [Tese de Doutorado]. Rio de Janeiro: Escola Nacional de Saúde Pública Sergio Arouca, Fundação Oswaldo Cruz; 2018.

9. Bresan D, Pontes ERJC, Leite MS. Fatores associados ao peso ao nascer de crianças indígenas Terena, residentes na área urbana de Campo Grande, Mato Grosso do Sul, Brasil. Cad Saúde Pública 2019; 35 Suppl 3:e00086819.

10. Pícoli RP, Carandina L, Ribas DLB. Saúde materno-infantil e nutrição de crianças Kaiowá e Guaraní, Área Indígena de Caarapó, Mato Grosso do Sul, Brasil. Cad Saúde Pública 2006; 22:223-7.

11. Wehby GL, Gili JA, Pawluk M, Castilla EE, López-Camelo JS. Disparities in birth weight and gestational age by ethnic ancestry in South American countries. Int J Public Health 2015; 60:343-51. 


\section{Resumo}

O peso ao nascer é um importante preditor de morbimortalidade perinatal, infantil e pré-escolar. São escassas as informações sobre o peso ao nascer das crianças indígenas no Brasil. O estudo teve como objetivo analisar o peso ao nascer das crianças indígenas, com base nos dados do Primeiro Inquérito Nacional de Saúde e Nutrição dos Povos Indígenas, Brasil (2008-2009). Este é o primeiro estudo a avaliar o peso ao nascer de crianças indígenas com base em uma amostra nacional representativa. Foram calculadas as médias e desvios-padrão de acordo com macrorregião, sexo, tipo e parto e local do parto. Foram utilizados o teste de qui-quadrado para analisar as diferenças de proporções e os testes de Kruskal-Wallis e $U$ de Mann-Whitney para diferenças nas médias, considerando o desenho amostral do estudo e a normalidade dos dados. Para 26,7\% das 6.128 crianças da amostra, não foi possível localizar qualquer registro de peso ao nascer nos documentos consultados. Entre as 3.994 crianças incluídas nas análises, o peso médio ao nascer, independentemente de sexo, tipo de parto e local do parto, foi $3.201 \mathrm{~g}$ (desvio padrão - DP $\pm 18,6 \mathrm{~g})$. A prevalência de baixo peso ao nascer foi $7,6 \%(n=302)$, significativamente mais alta em meninas. Os meninos apresentaram peso médio ao nascer significativamente mais alto que as meninas, independentemente de região. A frequência de baixo peso ao nascer foi ligeiramente mais baixa que nas crianças brasileiras em geral. O estudo aponta para a necessidade de melhorar a assistência pré-natal e a qualidade dos registros das consultas das mulheres indígenas, como estratégia para promover a segurança na gravidez e no parto.

Saúde de Populações Indígenas; Índios

Sul-Americanos; Peso ao Nascer; Saúde da

Criança; Indicadores de Desigualdade em Saúde

\section{Resumen}

El peso al nacer es un predictor importante de morbimortalidad perinatal, infantil y preescolar. La información sobre el peso al nacer de niños indígenas es escasa. El objetivo de este estudio fue analizar el peso al nacer de los niños indígenas, basado en datos de la Primera Encuesta Nacional de Salud y Nutrición de los Pueblo Indígenas, Brasil (2008-2009). Se trata del primer estudio dirigido al peso al nacer de niños indígenas, basado en una muestra representativa nacionalmente. Las medias y las respectivas desviaciones estándar del peso al nacer se calcularon según la región geopolítica, sexo, tipo de nacimiento y localización del mismo. Se usó un test chi-cuadrado para analizar las diferencias en proporciones y las pruebas Kruskal-Wallis y de la U de Mann-Whitney para las diferencias en las medias, considerando el diseño de la muestra del estudio y normalidad de los datos. Para un 26,7\% de los 6.128 niños incluidos en la muestra no fue posible localizar ningún registro de peso al nacer en los documentos investigados. De los 3.994 niños incluidos en el análisis, la media de peso al nacer, independiente del sexo, tipo de nacimiento, y lugar de nacimiento, fue $3.201 \mathrm{~g}$ (desviación estándar - SD $\pm 18,6 \mathrm{~g}$ ). La prevalencia del bajo peso al nacer fue 7,6\% $(n=302)$ y fue significativamente más alta entre niñas. Los niños presentaron significativamente una media más alta de peso al nacer que las niñas, independientemente de la región. La frecuencia del bajo peso al nacer fue ligeramente más baja que la observada en niños brasileños en general. Este estudio presenta aspectos que se necesitan mejorar en el cuidado prenatal y en la calidad de los registros de las consultas de mujeres indígenas, como una estrategia para promover un embarazo y parto seguros.

Salud de Poblaciones Indígenas; Indios Sudamericanos; Peso al Nacer; Salud del Niño; Indicadores de Desigualdad en Salud
Submitted on $30 / \mathrm{Jul} / 2020$

Final version resubmitted on $08 /$ Oct $/ 2020$

Approved on 19/Oct/2020 